\title{
Moiseeva A.V. \\ Revisiting the creolisation manifestation in the text of advertisement
}

Bashkir State University

(Russia, Ufa)

doi: $10.18411 / l j-11-2020-204$

idsp: ljournal-11-2020-204

\section{Аннотация}

В статье рассматриваются отношения компонентов невербальных средств письменной коммуникации, обладающих богатейшим потенциалом варьирования различных смыслов, передачи тончайших оттенков значения вербальных элементов текста, a также, участвующих в формировании наглядности при передаче представляемой авторами информации.

Ключевые слова: креолизованный текст, вербальный текст, цельность, связность, лингвовизуальное образование.

\section{Abstract}

The article examines the relationship between the components of non-verbal means of written communication, which have the richest potential for varying various meanings, conveying the subtlest nuances of meaning of the verbal elements of the text, as well as participating in the formation of visibility when transmitting information presented by the authors.

Key words: creolized text, verbal text, integrity, cohesion, linguo-visual formation.

Creolized and advertising texts are of considerable interest to modern linguists. The interaction of graphic-visual and illustrative-visual methods of presenting information, the mechanisms of their convergence, the similarities and differences in the impact of verbal and visual information, the communicative features of creolized texts attract the attention of researchers.

The widespread distribution of advertising, its impact on the literary language, the transformation of linguistic categories in the context of advertising discourse, suggestive potential, the active role of visual elements in advertising communication are actively discussed, including in linguistics.

It should be noted that the strategy of the authors of creolized advertising texts consists in the most complex suggestive influence on the recipient and is implemented through a onetime manipulation at the levels of different semiotic codes.

Summarizing the provisions adopted in Russian linguistics in relation to creolized texts, we can conclude that the methods of creating creolized texts consisting of verbal components and images are divided into three main models:

1. verbal text + image: images are added to the original verbal text;

2. image + verbal text: accompanying elements are added to the illustrative visual elements, verbal components;

3. verbal text = image: the text is initially created as creolized, verbal and illustrative-visual components are selected specifically to interact with each other.

It is worth pointing out that not only texts are creolized, but also structurally smaller verbal language units - lexemes. In addition, in terms of advertising discourse, the connotative potential of fonts and colors is actualized. Besides the verbal means of representation (double actualization, antithesis, pleonasm, oxymoron), there are their visual analogs, the inclusion of which in the verbal text contributes to its creolization.

In modern Russian, some verbal elements of the language (letters, morphemes, words) are replaced by their visual counterparts - iconic printed symbols, which are one of the most 
important means of text creolization. Dynamic creolized texts also function along with the static ones.

Obligatory features of the text are traditionally called integrity and coherence. Integrity is the unity of the theme of the text, as well as problems and ideas in works of art.

The coherence of a text is the connection of its individual elements as part of a large whole. A number of levels are distinguished that ensure the coherence of the text: the grammatical level, which ensures the structural coherence of the text; the semantic level, providing the internal, semantic unity of the text; the communicative level, which ensures the constant advancement of the text from a given (known, topic) to a new (unknown, topic); the cognitive level, which ensures the coherent unity of the text.

In defining the essence of a given linguistic unit, the key role belongs to the producer of the text; for its definition, it is necessary to mention the concept of the author's image (the terminology of V.V. Vinogradov). In each text, the interaction of both the author and the recipient of information is carried out in the process of communication, therefore the image of the recipient is highlighted as an important connecting element of the text. The image of the recipient is defined as the expression of the personality of the addressee of speech in various types of texts.

Intertextuality is an important property of the text. From a linguistic point of view, intertextuality is defined as the correlation of a specific text with the entire collection of previous texts, with the entire human cultural heritage, which is determined by its anthropological essence.

The expansion of the sphere of interests of modern linguists made them pay attention to non-verbal means of communication and their interaction with traditional, verbal ways of presenting information. The object of study was texts in which the verbal and illustrativevisual series create a single visual, structural, semantic, functional and communicative whole [Moiseeva 2014].

There are different texts in which the illustrative-visual series acts as an optional and as an obligatory element. Modern scholars offer a gradation of texts according to the degree of cohesion of verbal and non-verbal components in them: homogeneous verbal texts paralinguistically active texts - texts with partial creolization - texts with full creolization [Anisimova 2003]. For generic characteristics of inhomogeneous speech formations, the term semiotically enriched text is used. The term "creolized text" is used to denote "texts with full creolization", and "texts with partial creolization" are regarded as semiotically enriched texts.

The problem of the integrity and coherence of the creolized text was first identified and most fully developed in the science of language by E.E. Anisimova. The integrity of the creolized text is determined by the communicative-cognitive attitude of the addressee. According to the researcher's observations, "in speech, a creolized text appears as a complex text formation, in which verbal iconic elements form one visual, structural, semantic and functional whole, aimed at a complex pragmatic effect on the addressee" [Anisimova 2003: 17].

The connectivity of the verbal and illustrative-visual components of the creolized text is displayed at several levels: content, content-linguistic, content-composition. The content level corresponds to the semantic level. The content-linguistic level in the researcher's theory corresponds to the grammatical level in our understanding.

For a creolized text in the narrow sense of the term, the correlation of the iconic component with the letter and the word is relevant, since in such cases the pictorial series acts as an obligatory element of the text. The correlation of the iconic component with large parts of the verbal component of the text, as a rule, is optional, that is, in such cases, we are dealing not with creolized, but with semiotically enriched texts. The type of correlation of an image with a letter and a word refers to the semantic level of coherence of the creolized text (in the narrow sense of this term). 
A feature of the image of the author of creolized texts is the presence of several authors, their multi-authorship. In the process of creating printed creolized texts, there is an interaction of two types of art - verbal and visual. For the final text to be creolized, it is necessary to completely merge the author's images.

From the point of view of the category of the recipient's image, creolized texts are aimed at such a type of reader who quickly reads the information he needs, when reading he focuses on the brightest places, pays attention to the unusual and colorful. This type of recipient perceives the means of different semiotic codes in a complex manner, in the process of perception it is capable of performing synthesis operations.

The intertextuality of the verbal part of creolized texts is mainly manifested in the same way as in homogeneous verbal texts. The illustrative-visual part of the creolized text is based on the visual experience of the author.

The term creolized text is defined as a combined grammatical, semantic, communicative and cognitive link inhomogeneous linguovisual education, consisting of verbal and illustrative-visual sign units, created through the interaction of several authors, expressing an attitude to the described, aimed at a certain type of addressee and associated with the previous cultural tradition.

Creolized advertising texts are characterized by the implementation of the categories of integrity and coherence, inherent in all types of creolized texts.

Unlike conventional written communication, advertising communication is complicated by an additional subject. Regular print communication consists of the following participants: author - illustrator - print publication - reader.

The component diagram of the participants in advertising communication is as follows: advertiser - author - illustrator - consumer. The authorship of advertising texts is distributed between the advertiser and the copywriter. This feature determines the predominant anonymity of advertising texts. Carriers of the author's speech in advertising are divided into two types: narrator (impersonal, non-personified narration); narrator (conditional personified image).

The absence of authorship allows one to pass off one's subjective attitude towards the described phenomena (subjective modality) as an objective state of affairs (objective modality). It is the ability to pass off subjective modality as objective that is the main feature of the implementation of the author's image category in advertising texts.

The image of the recipient is determined by the target audience of advertising texts, which is understood as a group of people united by some common features, which are based on the methods of marketing communications used by commodity producers. In advertising texts, the target audience is designated by two methods: directly (direct calls to the object of advertising, direct indication of addressees, inclusion of an image of a "typical representative" of the target audience) and indirectly (using fonts, colors, slang vocabulary, formations of incorrect grammatical forms, images relevant to target audience of images, etc.).

Thus, by the advertising text we mean an integral and coherent sequence of sign units created by the author or a group of authors, having a suggestive character, positively describing its object, designed for a strictly defined target audience and associated with the previous cultural tradition.

$$
* * *
$$

1. Анисимова Е.Е. Лингвистика текста и межкультурная коммуникация. - М.: Академия, 2003. - 128 c.

2. Моисеева А.В. О связи вербального и невербального компонентов креолизованного текста гламурного журнала// Материалы III международной научно-методической конференции «Межкультурная-интракультурная коммуникация: теория и практика обучения и перевода». Уфа, РИЦ БашГУ, 2014. - С. 32-36. 